\title{
Title: A critical evaluation of year 7 students' reflections on the use of information skills when completing a curriculum related project.
}

\author{
James E Herring \\ Lecturer in Teacher Librarianship \\ Charles Sturt University \\ Australia
}

\begin{abstract}
While there have been a large number of books, articles and reports on information literacy in schools, there is a lack of empirical evidence in relation to the use of information literacy models in schools, Wolf (2003) and Herring, Tarter and Naylor (2000 and 2002) being exceptions. The purpose of this pilot study was to examine students' reflections on the information skills process following the use of an information skills scaffold (the PLUS model) during the completion of an assignment in a secondary school in the UK. The study takes a constructivist approach and data was gathered via a post-assignment questionnaire given to students. Results show that students' confidence was variable at the start of the assignment; that students found the completion of a concept map to be generally helpful; that almost 50\% of students found that completing a concept map made them more confident; that students used the concept map when searching for information; that students used a range of print and electronic sources of information; that students' preferences for using particular types of resources included both print and electronic sources; that students found the PLUS model to be helpful with their project; and that most students were prepared to consider using the model when completing future assignments.
\end{abstract}

\section{Introduction}

This study took place in a state comprehensive school in Cambridgeshire, UK. The 95 students taking part in the study were completing a Religious Education (RE) assignment in which they had to research aspects of an Islamic religious festival. Students were required to identify an aspect of the religious festival, research that aspect and produce a portfolio which included a written investigation of their individual topic as well as a postcard sent from the festival to a friend or relative. The postcard part of the portfolio encouraged students to use the results of their research for the content of the postcard and to write concisely but informatively.

The students were provided with an information skills scaffold - the PLUS model on the school intranet as well as with guidance on the use of selected print and electronic 
information resources. The emphasis of this project was on students' effective use of a limited range of sources. The teachers and school librarian viewed this project as one which sought to improve students' identification of purpose and students' effective use of information resources. This was not a project which focused on students' ability to find information on their topic. The aim of the study was to identify students' views on their use of information skills and also to gauge some affective aspects of students' work when completing this assignment, including levels of confidence. Students' use of information skills within the context of an assignment may be seen as part of the development of information literate students in a school but it should be recognised that information literate students should have attributes which enable them to identify a purpose for, find and effectively use information within a wider context than that of a school assignment. This study was designed as a pilot study which might be followed up by further studies of students using a more complex methodology.

This paper will review the literature relating to information literacy, outline the methodology adopted for this pilot study, present the findings of the study, discuss potential conclusions and suggest areas for future research in this area.

\section{Literature review}

While there now exists a vast literature on information skills and information literacy, empirical research relating to information literacy in the school context is still relatively limited and research on the application of information literacy models is very limited. This review of the literature will critically examine some definitions of information literacy, information literacy models and information literacy research, with a view to placing the present study in a research context and posing questions about developing information literate students.

\section{How do we define information literacy?}

A teacher librarian attempting to find an agreed definition of information literacy in the school context will search in vain as there appears to be a) a large number of definitions and b) some contradictions in what different authors perceive information literacy to be. Perhaps the most commonly accepted definition is that produced by Doyle (1994) as a result of a Delphi study conducted. Doyle's (1994) definition, is recommended by Langford (1998, p.59) who points to the confusion in attempts to define information literacy, stating "Is it [information literacy] a concept or a process? ... Or is it a new literacy that has been transformed from existing literacies to complement the emerging technologies for which the Information Age students must be skilled?”. Doyle's (1994, pp. 2-3) definition is “focused on the attributes of one who is information literate" and defines a person who is information literate as someone who

"recognises that accurate and complete information is the basis for intelligent decision making; recognises the need for information; formulates questions on information needs; identifies potential sources of information; develops successful search strategies; assesses sources of information including computer-based and other technologies; evaluates information; organises information for practical application; integrates new information into an existing body of knowledge; uses information in critical thinking and problem solving”. 
While Doyle's (1994) definition appears comprehensive, it has limitations. For example, while a student might recognise the "need for information", this need must be defined in terms of a clear purpose if recognition is to be of value. Also, in the context of a school assignment, "intelligent decision making" may not be the most pertinent attribute to highlight first. This definition does not include reference to a student's self-reflection on or selfevaluation of herself or himself as an information literate student.

Moore (2002, p.2) argues that information literacy can be viewed as a "dynamic concept" relating to skills but also states that "Information literacy exists, in pedagogical terms, at the confluence of resource-based learning practice, constructivist and metacognitive theories”. Moore (2002) thus implies that a distinction has to be made, in examining definitions of information literacy, between the concept of information literacy and the development of information literacy in schools.

The AASL/AECT (1998, p.8-9) standards Information Power outline "The nine information literacy standards for student learning” which seek to define the attributes of an information literate student. These standards are very comprehensive and include statements relating to finding and using information, "literature and other creative expression of information”, independent learning, ethical responsibility and information technology. There is a distinct developed countries cultural bias in these standards and it can be argued that a person can be information literate but a) have little aesthetic appreciation of literature b) may not be a democrat and c) may not always use information for ethical purposes.

There are a number of authors who criticise the concept of information literacy, often viewing definitions as being too narrow. Williams (2001, p.1) takes a critical view of definitions of information literacy and argues that "Definitions of information literacy, drawn from many perspectives, seem to situate themselves outside the actual learning process" [Williams' italics]. Williams (2001) raises questions about information literacy "an often used but dangerously ambiguous concept" and whether, in the school context, there is a clear link to what students actually learn i.e. opposed to what they find out about in an assignment. Boyce (2004, p.21) argues that current views of information literacy in schools are "inappropriate for the new era of electronic communications technologies" as these views are based on "the will for print-based pedagogy to transcend the changing culture of our communications environment”. Boyce (2004) demands that the focus should be on critical literacies. Limberg (2005, p.47) argues that teacher librarians and teachers should shift their focus from information literacy as a means of students learning a process towards "students developing a repertoire [Limberg's italics] of understandings of information seeking and use”.

The above definitions are selected from a wide range but are representative of current views. It is clear that teacher librarians, teachers and researchers need to examine how they individually view the term "information literacy" and decide whether it is an overarching concept or ideal, a set of interlinking skills, a number of attributes or a means of thinking or knowing.

\section{Information literacy models}

The term "information literacy models" is used here in that models which have been developed aim to contribute to the development of information literate students but it is clear that none of the models seek to encompass all the attributes of , for example, the AASL/AECT (1998) standards. Loertscher and Woolls (2002, pp. 106-121) review a large number of information literacy models which have been developed for use in schools although evidence of whether many of the models are used schools is sparse. Marland's (1981) model contained nine steps for students to follow and these steps included the 
identification of an information need, finding, using and presenting information and reflecting on achievement. Marland's (1981) model has clearly influenced subsequent models and was a seminal text which changed the focus of teacher librarians and teachers from library skills to information skills.

Stripling's (1995, p.166) model has been influential in the information literacy literature but there is little evidence of its application in schools although it is aimed more towards teacher and teacher librarians than students. The model "should help students understand that learning is continual and recursive, and that the main goal is not a final product or solution but the formulation of ideas, understandings, and further questions" and therefore focuses on the broader issues of learning rather than on the completion of an assignment.

Kuhlthau's (2004) Information Search Process model, developed from her constructivist based research, has been a key influence in the education of teacher librarians, in information literacy related research and, to some extent, in the development of school library programmes. Kuhlthau's (2004) model, developed over a period from the 1980s was innovative in that it sought to identify the affective as well as the cognitive aspects of students' approach to researching assignments in schools. Kuhlthau's (2004) model examines students' feeling of uncertainty and anxiety at different stages of their research process and their increase in confidence as they progress.

The most commonly used model in schools in North America and some other countries is the Big Six model (Eisenberg and Berkowitz 1990). The Big Six model focuses on what Eisenberg and Berkowitz (1990) view as the students' "information problem-solving process" and is similar to the Marland (1981) model in that it identifies a number of stages such as Task Definition and Evaluation. The Big Six model focuses mainly on information skills as a process although it does contain elements of metacognition noted by (see below) Wolf (2003).

This author's PLUS model (Herring 1996, 1999 and 2004) contains the elements of Purpose, Location, Use and Self-evaluation. Loertscher and Woolls (2002, p. 116) state that the PLUS model contains elements of other models "while adding emphasis on thinking skills and self-evaluation". Herring (2004, p.75) argues that "The most important of these skills is Purpose, because if students fail to define their purpose well, they will inevitably struggle to find the right information sources and the information need”. Herring (2004) also states that the location of information rarely causes problems for students in terms of quantity but that students need to be taught how to find relevant information that is related to their purpose. The Use element of the model (Herring 2004, p.72) contains a complex mix of learning skills and student attributes such as "the ability to understand the content of what is being read, viewed or listened to and the ability to relate this to existing knowledge”. The Self-evaluation element of the model contains some aspects of metacognition in that it asks students to think about their use of the model and how they might apply it in future learning situations.

Information literacy models can be criticised in that they may not suit the learning styles of all students and there has been some criticism of models (e.g. Green 2004) for ignoring the needs of individual students. Many models appear to focus too much on the completion of an assignment and, indeed could be termed "assignment management models" although aspects such as reflection or self-evaluation in some models tend to counter this argument.

\section{Information literacy research}


Loertscher and Wools' (2002) overview of information literacy research is a valuable contribution to the area and Loertscher and Woolls (2002) cite 262 references to researchrelated literature. In the school context, the work of Kuhlthau (2004) has been the most influential. Kuhlthau (2004) reviews a number of research projects carried out from the 1980s onwards. Kuhlthau (2004, p.29) has consistently taken a constructivist approach to her research and states that one of the "vantage points" for her research "is an understanding of learning as a constructive process". Kuhlthau's (2004, p.37) studies in the 1980s broke new ground in information literacy research in the school context by examining not only how students went about finding relevant information for an assignment, with a focus on the task the students faced but also on "thoughts, feelings, actions, strategies and mood”. Kuhlthau's (2004) research with students of different levels and abilities demonstrated that some previously held beliefs within the library and information science world could not be justified. For example, in Kuhlthau's (2004) studies, students using a high number and wide range of sources did not necessarily learn more than other students. As this study sought to seek students' levels of confidence, Kuhlthau's (2004) work is pertinent.

Gordon (2000) studied students' use of concept mapping in the context of a school assignment and is of high relevance to this study. Gordon (2000) states that students who used concept maps were more successful in searching for information than students who did not use concept mapping. These students, according to Gordon (2000) used their concept maps to support more successful search strategies which focused on identifying relevant information and ideas and these students were also more likely to take a metacognitive view of the link between concept mapping and searching. Kinchin and Hay (2003, p. 43) studied the use of concept maps in science classes and argue that "concept mapping can be a helpful metacognitive tool, promoting understanding in which new material interacts with the students' existing cognitive structure”, but their research was not related to a wider view of concept mapping as part of information literacy teaching in the school. Cain's (2004) research found that the use of concepts maps in a primary school enhanced students' concentration; kept students on task more than previously; and encouraged students to improve their use of resources. Cain (2004) also states that students were able to relate the concept map to later stages such as writing. The research on concept mapping is relevant to this study as students were guided in using a concept map (referred to as a "mind map/spider diagram” in the school in this study).

Barranoik (2004, p.33) took a constructivist approach to examining how teachers and teacher librarians might develop students "to actually become architects of meaning”. One key aspect of Barranoik's (2004, p.34) study was that students identified a "meaningful project" as one in which students were given a choice of topic which "enabled them to select something that was of personal interest and stimulated their thought”. In the present study, students were asked to imagine their attendance at a religious festival and this parallels Barranoik’s (2004) assertion. Barranoik (2004) studied students at a higher level in school than the present study and some of her findings are less relevant than others but Barranoik (2004, p.36) concludes that "there is value in listening to what the students have to say about doing research projects”.

A number of research studies have focussed on students' information seeking and Branch (2001) who examined students' use of a CD-ROM encyclopedia states that students often had problems in defining keywords for searching, were not keen to use advanced searching and often had problems in reading long articles. Branch (2001) also noted that students often showed feelings of uncertainty and lack of confidence, similar to Kuhlthau's 
findings, at the early stages of completing an assignment. Bilal (2004) studied the use by students of search engines such as Yahooligans! by students and states that students often lacked the necessary skills to use search engines effectively as they often lacked a clear purpose for their searches and often focused on finding exact answers to questions instead of seeking to understand what they read. In this study, students had the option of using a search engine to find information for their assignment.

In relation to empirical research on the use of information skills models, Kuhlthau's (2004) studies are relevant but it can be argued that Kuhlthau's model is more geared towards use by teachers and teacher librarians than by the students themselves. Studies of students' use of models designed to be presented to and used by students are very limited, with Wolf (2003) and Herring, Tarter and Naylor (2000 and 2002) being exceptions. Wolf (2003) evaluated the use of the Big Six model as a metacognitive tool for students and her findings indicate that the model encouraged students to focus more on what they learned and also on the process in which they were engaged when completing an assignment. Wolf (2003, Conclusion, paragraph 3) states that her case study may indicate that models such as the Big Six provide students with "the elements for mental modelling so necessary in helping the novice construct a method to meet the information use tasks placed before him or her".

Herring, Tarter and Naylor (2000) evaluated the use of the PLUS model in a UK secondary school and focused on students' use of brainstorming and concept mapping, how students used keywords for searching and in reading for information, students' note taking strategies and assignment writing strategies. The study also asked students to comment on how useful they viewed the PLUS model. The findings of this study (Herring, Tarter and Naylor 2000) indicated that students found that the model useful in examining their existing knowledge, keeping them on track during the assignment and forming questions. The findings also showed that students valued the concept map as a means of defining purpose more easily and as an aid which could be used later in the assignment process. Herring, Tarter and Naylor's (2002) second study of the use of the PLUS model in the same school came to similar conclusions but the findings were extended to examine students' understandings of how they used information skills when completing their assignment and the extent to which they reflected on the use of these skills. Herring, Tarter and Naylor (2002) report that some students were able to view the use of information skills in a holistic and metacognitive way, for example by identifying the later use of the results of brainstorming and concept mapping. The findings also indicated that most students would use the PLUS model for subsequent assignments.

This selected literature review indicates that there is no clear agreement on what might constitute information literacy in schools. Indeed, there is some confusion about whether teacher librarians and teachers are seeking to teach a rather narrow set of skills which are mainly related to the completion of an academic assignment in a school or whether they should be attempting to develop information literate students i.e. students who take a metacognitive view of their use of information in a range of contexts. There also needs to be more debate about how information literacy in schools is related to what students learn and the extent to which students can transfer information skills and./or information literacy attributes across subjects and time.

\section{Methodology}

This research is based within the interpretivist position which seeks to understand the context of the study as well as how the participants construct meaning. It takes a 
constructivist approach which implies that the researcher is not seen as an objective observer, seeks to engage with the participants and interprets the findings (Williamson 2002). This pilot study was designed to examine the views of year 7 students on their use of information skills when completing a curricular assignment. According to van Teijlingen and Hundley (2001), pilot studies can be seen as a mini-version of a larger study or as a testing of a particular research instrument. van Teijlingen and Hundley (2001, table 1) provide a list of reasons for completing a pilot study and these include "Assessing the feasibility of a (full scale) study/survey", "Collecting preliminary data" and "Developing and testing adequacy of research instruments" and these were the key aspects of this pilot study. From the evaluation of this pilot study, it is hoped that the researcher may be able to develop a larger study, involving more schools and using constructivist grounded theory (Charmaz 2005) as a methodological approach. Sampling for this pilot study was opportunistic (Gobo 2004) as the school was using the author's PLUS model and there was agreement with the school management and the teachers involved that the year 7 classes would be suitable for this type of study. A pilot study of this kind cannot be seen to be representative of either other classes or years in the school used nor can it be generalisable to schools as a whole. The method of data collection was a post-assignment questionnaire issued to students. The questionnaire was designed to provide both quantitative and qualitative data which could be used to inform but not be part of, a larger study (van Teijlingen and Hundley 2001). Best and Kahn (2003) state that questionnaires which are issued in person can gain the trust of respondents where respondents are readily available but also point out that disadvantages of questionnaires may include the possibility of poor responses being provided by participants. Another potential disadvantage of a post-assignment questionnaire is that some students' recall of their feelings or actions during the assignment process may not be comprehensive. Data analysis was done by coding student responses and establishing and comparing categories which emerged from the coding and this approach is recommended by Lee and Fielding (2004) for this type of research.

\section{Findings and discussion}

\section{Student confidence in finding and using information}

Students were asked to indicate how confident they felt about finding and using information when they started their RE assignment and Figure 1 shows the students' responses, with most students stating that they were quite confident (58\%) or very confident (15\%) but with a significant number of students (21\%) stating that they were unsure of their ability to find and use information. Only $6 \%$ of students did not think they would be able to find and use information. Students were then asked to briefly explain why they felt like this and there was a wide range of responses from students. Data coding produced a number of categories which demonstrate factors which affected the students' levels of confidence. 
Not able to find and use information $(6 \%)$

Not sure about finding and using information (21\%)

Quite confident in finding and using information (58\%)

Very confident in finding and using information (15\%)

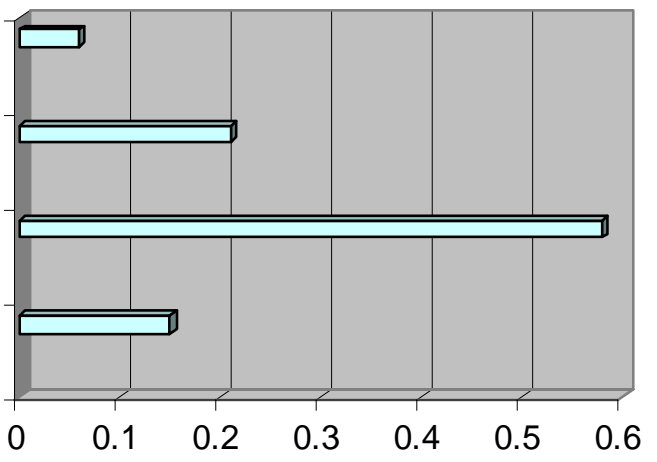

Figure 1 Students' confidence in being able to find and use information 
Where students took a positive view of their ability (i.e. very confident or quite confident), the largest category was the students' confidence in knowing how to go about finding and using information and comments included "I felt quite confident because I knew how to gather the information and knew what to do", "Because I knew which books to look in and what websites to go in" and "I knew where to find all the information in the books and the internet”. The second highest category related to students' previous experience of completing assignments and finding and using information and comments included "Because I had done this kind of thing in primary school. I am used to looking in books and also writing notes", "I felt that I was quite confident as I have done this type of thing before in previous years" and "Because I did this kind of thing in primary school”. The third highest category was related to the use of computers, including internet use and comments included "Because I know how to use the computer and library system", "Because I go on the internet a lot, so it's very easy for me to find information" and "Because I have used a computer before so I knew how to get information from there". Students also highlighted having access to the internet at home as a factor, with responses such as "Because I have resourceful parents and internet at home" and "Because I have a computer at home and I have to find information for homework". Some students who were very confident showed a general level of self confidence and comments included "Because I'm quite good at this sort of thing" and "I felt confident about my work and that it was right”.

Where students were less confident, there was also a range of responses and categories where students stated that they were not sure about whether they would be able to find and use information included uncertainty about the process ("I had never been on the PLUS Learning Zone so I wasn’t quite sure where to find information”) , problems in using sources ("I felt like this because the websites weren't very understandable") and lack of subject knowledge ("Because I'd never done anything on Hajj before". Those students who indicated that they did not feel able to find and use information showed a general lack of confidence and comments included "Because I am not usually quick minded and can't find information easily" and "Because I am not very good with finding things in books and not much better on computers".

The findings show that most students were fairly confident about their ability to find and use information but they expressed their reasons for this confidence in a range of ways. Although students did not express it in this way, it may be that students' previous experience was a larger factor, in that students who expressed confidence in knowing how to find and use information, did so because of previous experience. It should be noted that students responses focused on finding information and any future study would separate "finding" and "using" information. Students thus displayed affective aspects of their experience and while some students showed similar responses to studies by Kuhlthau (2004) and Branch (2003), it should be noted that this study did not ask students about confidence levels in relation to completing their assignment but only in relation to finding and using information. There is some evidence here of students taking a metacognitive view, similar to that found by Wolf (2003), in that many students were able to relate their previous experience of the assignment process to this assignment. Students' comments on using sources mostly contained reference to computers or the internet and it appears to indicate that students viewed digital resources as very important, especially where they had access to the internet at home. 


\section{Students' views on concept mapping}

Students were asked how helpful it was for them to complete a concept map (referred to as "mind map/spider diagram" in the questionnaire) before looking for information. The responses (see Figure 2) indicate that $76 \%$ of students found the concept map to be either very helpful or quite helpful and $24 \%$ of students found the concept map to be either not very helpful or not helpful at all.

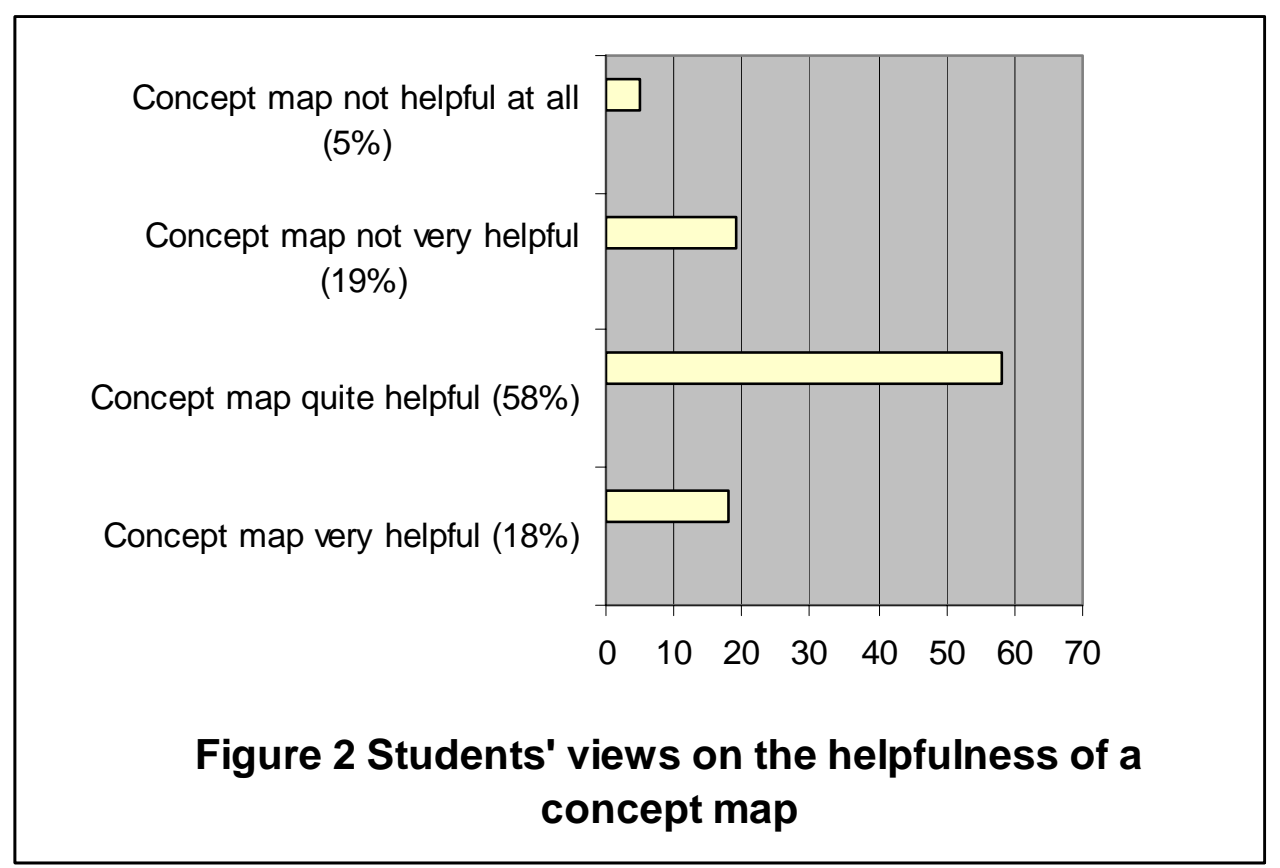

Students were then asked to express a view on whether the completion of the concept map made them more or less confident about completing a successful postcard or whether it had no effect on their confidence. Opinion (see Figure 3) was evenly split between those indicating that completing the concept map made them more confident (48\%) and those who thought that completing the concept map had no effect on their confidence (46\%). Only 6\% of students indicated that it made them less confident.

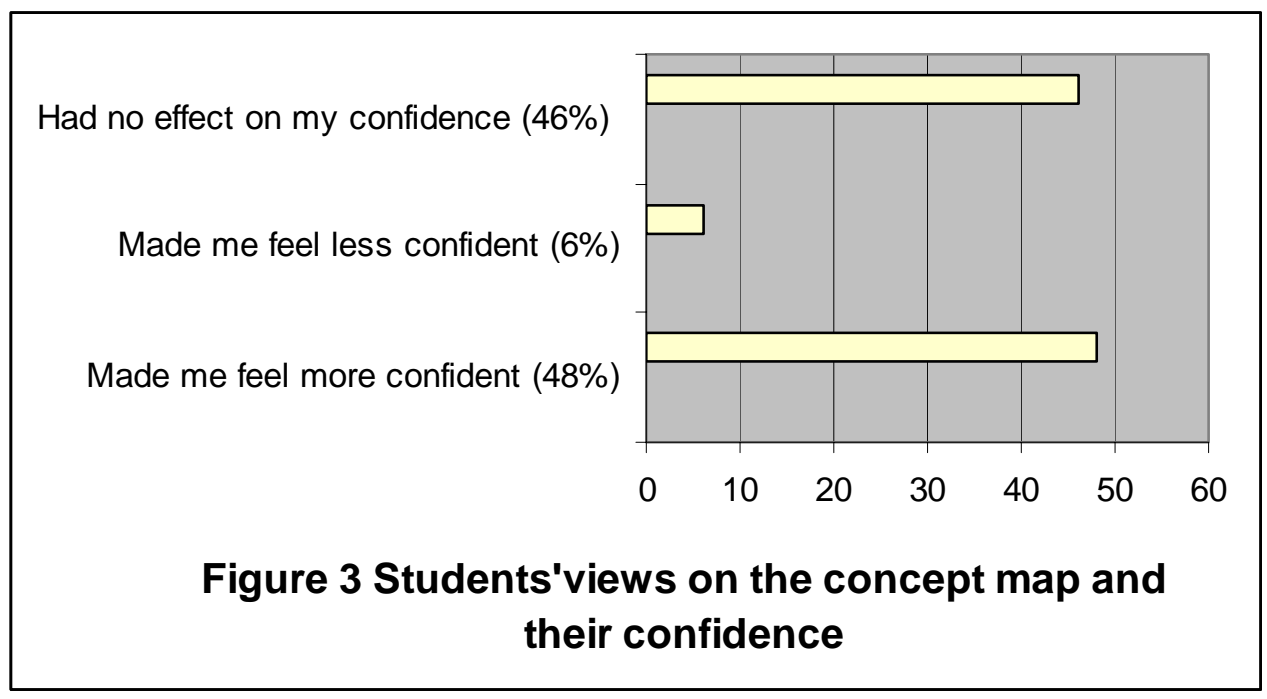


Students were asked to indicate why they felt the way they did about the concept map's effect on their confidence. For those students who felt that the concept map made them more confident, the main categories to appear, in order of importance, were related to the subsequent usefulness of the concept map, understanding the topic or the process, and being organised. Students felt more confident as the concept map was seen as a tool which could be used later in the assignment process and comments included "Because it gave me things to write about so I didn't have to think off the top of my head when it came to writing the postcard”, "It made me more confident as I had something to look at if I was stuck" and "Because I knew what I had to answer and what to look for on the internet". Students also felt more confident when the concept map added to their understanding of the topic or the assignment process and comments included "Because I [then] knew what Hajj was so I didn't get stuck doing the postcard" and "It helped me know what to look for". The concept map was also seen as enabling students to be more organised and more confident and comments included "I felt I was then ready to do my postcard - I was prepared" and "It was really useful as it told us exactly what we needed to do".

For those students who indicated that the concept map had no effect on how they felt about doing the postcard, there was a range of reasons given with two main categories which were that students did not see a need for the concept map ("Because I already knew what I was doing” and "Because I didn't feel that I needed to do it") and that the concept map was not effective ("Because it would hardly have any effect on my final work" and "Because it didn't explain enough about it”). Other much smaller categories related to students' use of other methods, students who viewed the concept map as helpful but not affecting their confidence and students who viewed the concept map as not being of use later.

The above findings about students' views of the value of concept maps match the findings in the literature review to some extent. Students who saw the concept map as increasing their confidence (48\%) reflect the views of Gordon (2000) and Cain (2004) in that these students can be seen as taking a metacognitive view of concept mapping by identifying its usefulness in later stages of the assignment process i.e. these students think about the assignment process and the information skills process in a holistic way. Those students who identified the concept map as increasing understanding reflect the views of Kinchin and Hay (2003). It is clear that while most students (83\%) viewed the concept map as quite or very helpful, not all of these students saw the concept map as increasing confidence and this reflects the findings of Herring, Tarter and Naylor (2002) where it was found that a minority of students did not see a need for a concept map, as it did not match their learning style. In this study, it is clear that the use of a concept map was an aid to most students as it helped them to understand the topic, organise their thoughts and use the contents of the concept map at a later stage.

\section{How students searched for information}

Students were asked to indicate how they went about finding useful information for their assignment and were given a list of choices and were able to select multiple choices. Figure 4 shows the choices made by the students and indicates that most students (75\%) searched using 'Hajj' as the main keyword. Only $26 \%$ of students stated that they used the keywords from their mind maps which may contradict the finding above about the usefulness of the concept map. Where students indicated 'another way' of finding information, the main categories identified were the use of book indexes and browsing through books. 


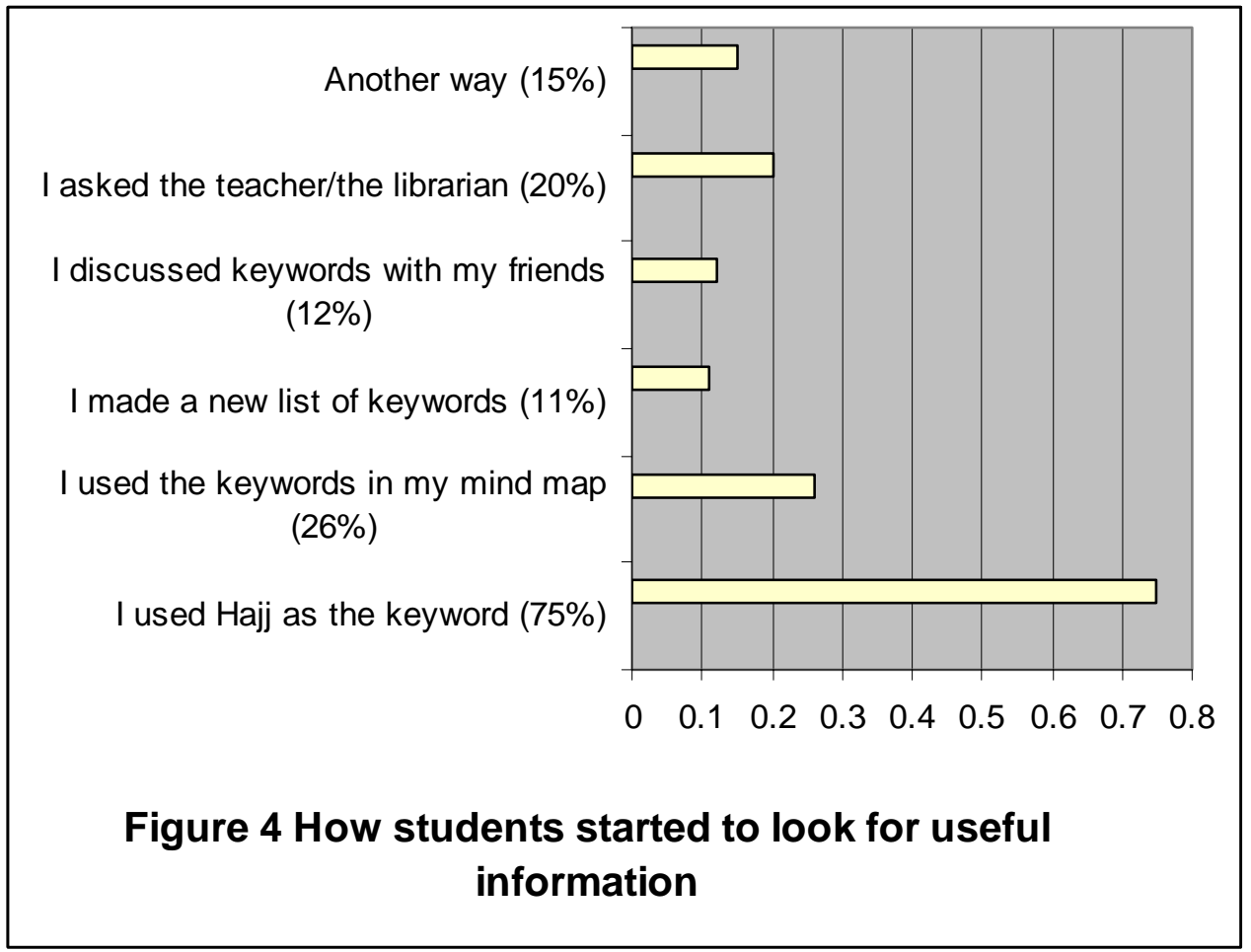

Students were then asked to indicate which sources they used from a list (See Figure 5) when they searched for information. Only 4 students indicated 'another way' which include use of the library's OPAC and asking a friend. It is interesting to note that students were heavy users of the RE learning zone as a guide for them to use sources and also that there was a high use of books as well as search engines. Many students indicated that they used three or more sources of information. 


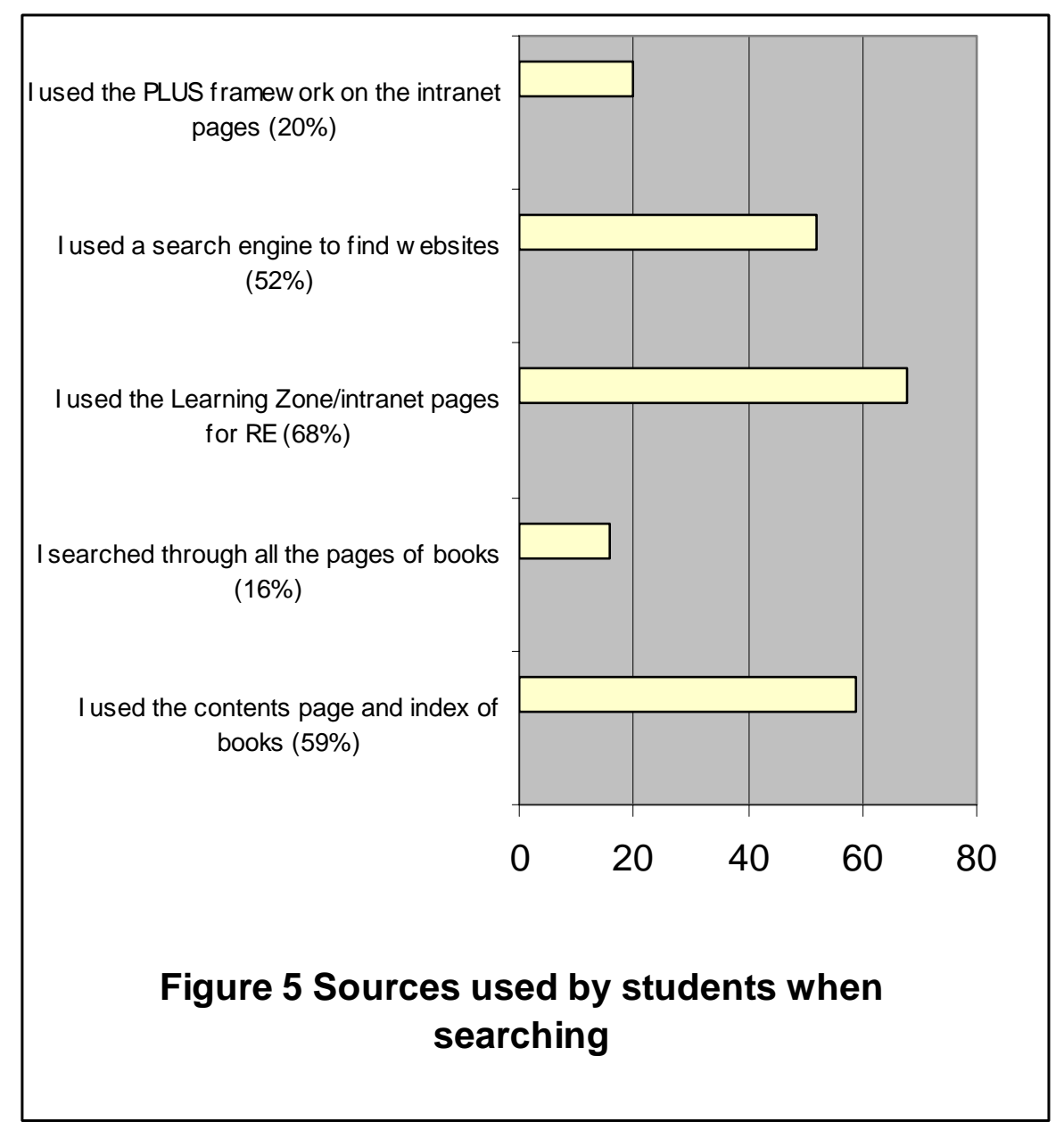

In relation to searching for information, students were also asked to indicate which sources they though might be most useful for them to use and Figure 6 shows the students choices. In this question, students were asked to indicate only one source of information. Results show that more students preferred to use websites than books, although there was a significant number of students who showed a preference for mainly books and for both books and websites. 


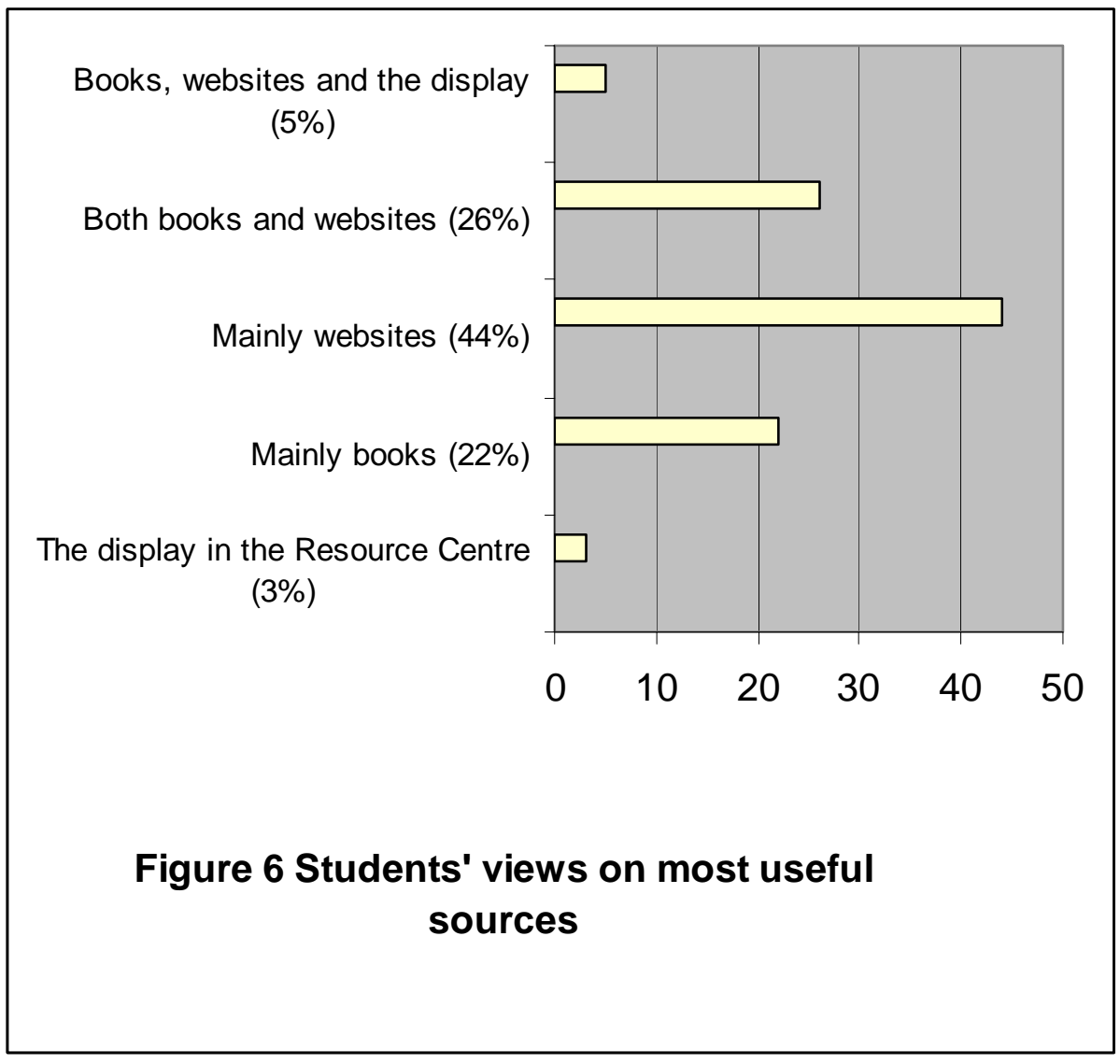

When students were asked to comment on why their choice would be most useful, there was a wide range of comments although most comments from students were fairly superficial. Students expressing a preference for books mainly emphasised quantity - of books or of information ("Because there are more books to read and more information in there" and "Because they have a lot of information on what you want"). Students also stated that books were easier to use ("It is easier sometimes to look through books"). A minority of students who preferred books indicated criteria such as trust, accuracy and understanding as a reason for their preference. Students who preferred to use websites also mostly emphasised the quantity of information in websites ("I think this because the internet has lots of information in many different ways" and "Because the internet has lots of information and loads of websites"). Students also expressed the view that websites were easier to use ("I thought this because it's easy to get information from search engines”). A minority of students cited criteria such as websites being more up to date and being more reliable. Students who indicated that they preferred to use both books and websites emphasised the value of variety and range ("Because you would be finding more information from different sources”) as well as quantity.

Studies of students' preferences for websites or books or a combination of both are rare but Lenhart, Simon and Graziano (2001) reported that 71\% of high school students stated that the Internet was the major source for their most recent major school assignment. Lorenzen's (2003) study found that while students made much use of websites for school work, many students expressed a preference for using both books and websites. Herring and Tarter (2006) found that $60 \%$ of students preferred to use websites for school work than books. This study thus mainly reflects the findings of the literature on student preferences. 
Students were finally asked whether they might use the PLUS model for assignments in other subjects. Figure 7 shows the responses, with $65 \%$ of students intending either to think about using the model or definitely intending to use it and $35 \%$ of students who will probably or definitely not use the model again. The findings here corroborate those of Herring, Tarter and Naylor (2002) in relation to students' likely future use of the PLUS model.

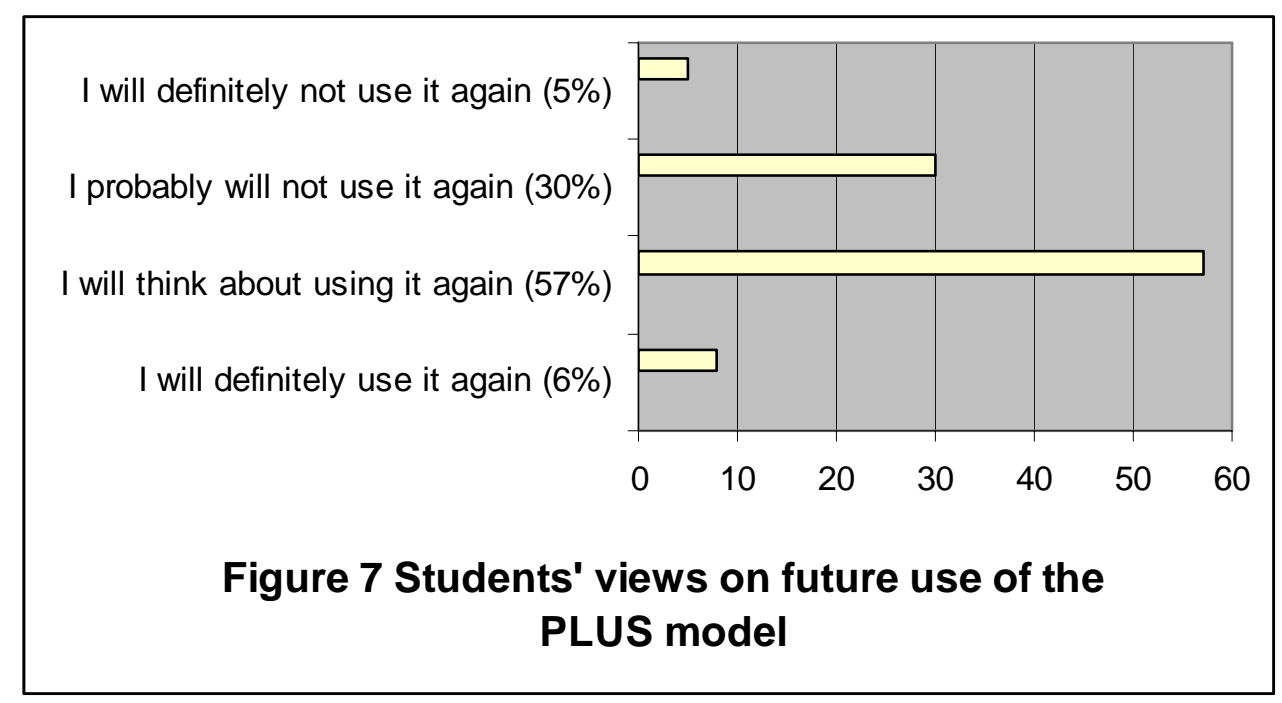

\section{Conclusions and future research}

As this pilot study shows the findings of the views of students in one class of one school in the UK, it is not possible to draw generalised conclusions which might be applicable in other schools or in other countries. What can be drawn are potential conclusions which might be of interest to teacher librarians and teachers in schools across the world. The key potential conclusions are:

Post-assignment questionnaires are a rich source of data which can reveal aspects of students' views which might not be known to teacher librarians or teachers

While most students appeared to be confident of finding information, there was little evidence of students expressing views on using information and students may need to be focused more on this aspect

While most students found concept maps to be helpful and a source of confidence, the use of keywords in these concepts maps was limited when students expressed views on searching for information. Students may need more help in the use of concept maps

Students' searching for information indicated high use of intranet pages but also high use of a single keyword (Hajj) when searching and students may need more advice on searching 
More students preferred to use websites than books but a significant number preferred either books or books and websites. Students should be taught to assess resources irrespective of format

Most students indicated that they would think about using the PLUS model in the future. Students should be encourage to think about models which may suit their own learning styles

From these conclusions, teacher librarians and teachers might wish to reflect on whether they gather any information on their students' views on the use of information skills; whether they provide students with an information literacy scaffold to support students who are completing assignments; whether they adequately teach students the potential use of concept maps; whether they can find ways of teaching students to take a metacognitive view of their information skills and information literacy attributes; and whether they know if students transfer information skills and information literacy attributes across time and subjects.

Future research in the following areas would benefit teacher librarians and teachers seeking to develop information literate students in today's schools:

$>$ Greater use of post-assignment questionnaires which seek to find out the views of students doing school assignments

$>$ More in-depth studies of students views using methods such as student journals, observation of students' searching, individual interviews with students and student focus groups

$>$ Studies which seek to discover the extent to which students transfer information skills and information literacy attributes across time and subject areas.

\section{References}

Best, J and Kahn, J (2003). Research in education. Boston, MA, Allyn and Bacon.

Bilal (2004) Research on children's information seeking on the web. In M Chelton and C Cool (Eds.) (Youth Information-seeking behaviour: theories, models and issues. Lanham, MD, Scarecrow Press

Boyce, S (2004) Information literacy and school librarianship: a critical look at pedagogy and profession. In S La Marca and M Manning (Eds.) Reality bytes: information literacy for independent learning. Melbourne, Vic., School Library Association of Victoria (pp.19-32).

Branch, J (2001) Information seeking processes of junior high schools: a case study of CD-ROM encyclopedia use. School Libraries Worldwide 7(1), 11-27.

Charmaz, K (2005). Grounded theory in the $21^{\text {st }}$ century: applications for advancing social justice studies. In $\mathrm{N}$ Denzin and Y Lincoln, (Eds.) The Sage handbook of qualitative research, $3^{\text {rd }} \mathrm{ed}$. Thousand Oaks, CA, Sage Publications (pp. 507-535).

Cain (2004) Using mind-maps to raise standards in literacy, improve confidence and encourage positive attitudes towards learning. National Teacher Research Panel. Retrieved 17 April 2006, from http://www.standards.dfes.gov.uk/ntrp/lib/pdf/Cain.pdf.

Doyle, C (1994) Information literacy in an information society: a concept for the information age. Syracuse, N.Y., ERIC Clearing House on Information \& Technology.

Eisenberg and Berkowitz (1990) Information problem-solving: The big six skills approach to library and information skills instruction. Norwood, NJ, Ablex.

Gobo, G (2004) Sampling, representativeness and generalizability. In C Seale, G Gobo, J Gubrium and D Silverman (Eds.) Qualitative research practice. London, Sage Publications (pp.435-457) 
Gordon, C (2000) The effects of concept mapping on the searching behavior of tenth-grade students. School Library Media Research, 2, article 6. Retrieved $17^{\text {th }}$ April 2006, from

http://www.ala.org/ala/aasl/aaslpubsandjournals/slmrb/slmrcontents/volume32000/mapping.htm

Green, G (2004) Teacher librarians and the culture of thinking: taking up the challenge. In S La Marca and M

Manning (Eds.) Reality bytes: information literacy for independent learning. Melbourne, Vic., School Library

Association of Victoria (pp. 67-74).

Herring, J (1996) Teaching information skills in schools. London, Library Association Publishing.

Herring, J (1999) Exploiting the internet as an information resource in schools. London, Library Association Publishing.

Herring, J (2004) The internet and information skills: a guide for teachers and school librarians. London, Facet Publishing.

Herring, J and Tarter, A (2006) Progress in developing information literacy in a secondary school using the PLUS model. School Libraries in View 23. In press.

Herring, J, Tarter, A and Naylor, S (2000) Theory into practice: Using the PLUS model to teach information skills and support the curriculum in a secondary school. In E Howe, E (ed.) Developing information literacy. Papers presented at the Fourth International Forum on Research in School Librarianship, Malmo, Sweden. Seattle, WA. International Association of School Librarianship (pp. 111-118)

Herring, J, Tarter, A and Naylor, S (2002) Herring, J, Tarter, A and Naylor, S 2002, An evaluation of the use of the PLUS model to develop pupils' information skills in a secondary school. School Libraries Worldwide. 8(1) 1-24.

Kinchin, I and Hay, D (2000) 'How a qualitative approach to concept map analysis can be used to aid learning by illustrating patterns of conceptual development', Educational Research 42(1) 43-57.

Kuhlthau, C (2004) Seeking meaning: a process approach to library and information services. $2^{\text {nd }}$ ed., Westport, CT, Libraries Unlimited.

Langford, L (1998) 'Information literacy: a clarification', School Libraries Worldwide, 4(1), 59-72.

Lee, M and Fielding, N (2004) Tools for qualitative data analysis. In Hardy, M and Bryman, A Handbook of data analysis. London, Sage Publications (pp. 529-546).

Lenhart, A Simon, M and Graziano, M (2001) The internet and education. Pew Internet and American Life Project. Retrieved April 17 2006, from http://www.pewinternet.org/pdfs/PIP_Schools_Report.pdf

Limberg, L (2005) Informing information literacy education through empirical research. In J Henri and M Asselin (Eds.) The information literate school community 2: issues of leadership. Wagga Wagga, NSW, Centre for Information Studies, Charles Sturt University (39-50).

Loertscher, D and Wools, B 2002, Information literacy: review of the research. ${ }^{\text {nd }}$ edition, Hi Willow Research and Publishing, Spring TX.

Lorenzen, M (2003) High school students and their use of the world wide web for research. Retrieved April 17 2006, from http://www.libraryinstruction.com/confusion.html

Marland, M (ed.) (1981) Information skills in the secondary curriculum. London, Methuen Educational.

Moore, P (2002) An analysis of information literacy education worldwide. White Paper prepared for UNESCO, the U.S. National Commission on Libraries and Information Science, and the National Forum on Information Literacy, for use at the Information Literacy Meeting of Experts, Prague, The Czech Republic. Retrieved 17 April 2006, from http://www.nclis.gov/libinter/infolitconf\&meet/papers/moorefullpaper.pdf

Stripling, B (1995) Learning-centred libraries: implications from research. School Library Media Quarterly, 23(3). Retrieved 17 April 2006, from http://www.ala.org/ala/aasl/aaslpubsandjournals/slmrb/editorschoiceb/infopower/selectstripling1.htm

van Teijlingen, E and Hundley, V (2001). The importance of pilot studies. Social Research Update 35. Retrieved April 14, 2006, from http://www.soc.surrey.ac.uk/sru/SRU35.html

Williams, D (2001) Information literacy and learning on-line. In SCROLLA Networked Learning Symposium, University of Glasgow, 14.11.01. Retrieved 17 April 2006, from http://www.scrolla.ac.uk/resources/s1/williams_paper.pdf

Williamson, K (2002) Research methods for students, academics and professionals: information management and systems. $2^{\text {nd }}$ ed., Wagga Wagga, NSW, Centre for Information Studies, Charles Sturt University.

Wolf, S (2003) The Big Six information skills as a metacognitive scaffold: a case study. School Library Media Research, 6, article 3. Retrieved 17 April 2006, from http://www.ala.org/ala/aasl/aaslpubsandjournals/slmrb/slmrcontents/volume62003/bigsixinformation.ht $\mathrm{m}$ 
Reproduced with permission of the copyright owner. Further reproduction prohibited without permission. 